\title{
Diversity of Argumentative Processes and the Construction of a Culture of Argumentation in two Science Classrooms
}

\author{
Ana Paula Souto Silva Teles, Danusa Munford
}

\begin{abstract}
Keywords Abstract This study aims to understand aspects of the construction Argumentation of a classroom culture that foster argumentation by contrasting Processes; argumentative processes in two different middle-school classrooms. Science classroom We adopted tools from interactional ethnography, and we adapted culture; elements of the Theory of Argumentation Pragma-Dialects. We Pragma-Dialectics conducted participant observation with records in field notes and theory of video. The results evidenced that the construction of a culture argumentation. that foster argumentation occurs over time and it involves diverse argumentative processes. In both classrooms we observed that the forms that teachers interacted with students contributed to promote differences of opinion, and, hence, they supported a culture of argumentation. Students' forms of participation also contributed to the variation in argumentation because they interacted with the teacher, as well as, with their peers. The study has potential to contribute to teachers' practice and teacher education, as well as to advance our understandings about the diversity of argumentation processes.
\end{abstract}

Submitted on 11th November 2020 Accepted on 09th March 2020 Published on 28th July 2021

\section{Introduction}

Argumentation plays an important role in the learning process (Billig, 1987; Schwarz, 2009) and specifically in Science Education (Berland \& Reiser, 2011; Henderson et al., 2018), as it can contribute to the conceptual, epistemic and social development of students, among other aspects (Duschl, 2008);

However, there are many challenges to face so that argumentation is present in school science. One of these is to change the classroom culture so that it becomes a culture of argumentation (Henderson et al., 2018). Investigation of argumentation from this classroom culture perspective allows dialogue with extensive and consistent production about this issue, but also brings new questions and new challenges. In this study, first we shall carry 
out a consideration of this notion of 'culture of argumentation' and study characteristic aspects of a culture, through dialogue with literature. These aspects guide our analyses, based on elements of Ethnography in Education and the Pragma-Dialectics theory of argumentation, these being theoretical and methodological perspectives that allow dialogue with the notion of culture and discourse as action. In this regard, we seek to take up a perspective that is more descriptive rather than normative, noting that this 'description' does not mean that we do not aim to explain phenomena, or the absence of theorisation. The distinction between descriptive and normative research is used to emphasize the centrality of participants' perspectives for understanding phenomena (Kelly, 2005).

Our main goal in the present study is that of understanding aspects of the construction of a classroom culture of argumentation through the contrast between argumentative processes in two middle school/secondary classrooms. In this regard, our research questions are: In which aspects are the argumentation processes in $8^{\text {th }}$ grade classes, (one of regular education and another in Adult Education), and in which are they different? How are the argumentative processes of the two groups related to the construction of a culture of argumentation in the classroom?

\section{Aspects of Culture of Argumentation in the Classroom}

Henderson and collaborators (2018) give prominence to the centrality of the change of classroom culture, towards an occurrence of argumentation. Sandoval et al. (2019) say that culture of argumentation corresponds to "a context where norms and practices of argumentation develop to meet collective goals" (Sandoval et al., 2019, p. 16). Based on this definition, we can see that argumentation is understood as a cultural practice rather than as a skill, and that the focus is on the group and not on the individual. These practices are 'ways of speaking and acting that are enacted by community members according to shared norms attached to specific roles.' (Sandoval et al., 2019, p. 2).

To define the central aspects of culture of argumentation, we seek to establish a closer dialogue with the specialised literature. Henderson and collaborators (2018) and Sandoval and collaborators (2019) explicitly address the culture of argumentation within Science Education. However, other studies, even without investigating argumentation from the cultural standpoint, also bring important contributions to make it possible to characterise aspects of this culture.

The first aspect of a culture of argumentation in the classroom environment involves doubts and uncertainty. According to Henderson and collaborators (2018), the construction of this type of culture in the classroom is linked to changes in epistemologies of Science among teachers and students. In this regard, these authors suggest the need for scientific knowledge to be seen as something temporary, subject to doubts and uncertainty. This means that when students regard scientific knowledge as being something temporary, they feel more comfortable in defending their points of view should these be in opposition to scientific knowledge. 
For example, El-Hani and Mortimer (2007) justify the existence of these points of view in opposition to scientific knowledge based on the cultural and linguistic diversity of the students who, when present in the classroom, generate constant tension between different kinds of knowledge, whether visible or not. In this regard, Henderson and collaborators (2018) suggest that a classroom culture that favours uncertainty and doubt breeds conditions that would make the students' epistemologies visible and, as a result, show up the differences between types of knowledge.

The emergence and solution of disagreements are also suggested by Sandoval and collaborators (2019) as important aspects for a culture of argumentation. In this regard, these authors suggest that students need to be engaged with material resources that can be used to generate and solve any disagreements. However, in our research we observe that disagreements may also arise in discursive interactions without there necessarily being any material resources involved (Munford \& Teles, 2013; Munford \& Teles, 2015).

Sandoval and collaborators (2019) evidenced that the children naturally disagreed about conceptual and methodological aspects related to what they were studying. Therefore, an analysis of when, how and by whom the disagreements and respective problem solving are generated can contribute to better understanding of the construction of a culture of argumentation.

The second aspect of a classroom culture of argumentation involves criticism and evalution. Indeed, Henderson and collaborators (2018) suggest a need to give greater emphasis on criticism of arguments, as there is excessive emphasis on construction of arguments, while scientific argumentation is not limited to a construction exercise.

González-Howard and McNeill (2020) support these authors, on defending the centrality of criticism for the construction, evaluation and review of knowledge during argumentation. According to these authors, criticism, as a scientific practice, enables the distribution of the epistemic agency and includes many types of dialogue interactions that contribute towards the collective construction of meanings. For example, evaluation of evidence and of the reasoning that colleagues come up with; questions made to each other; clarification of questions; criticism and debates about the power of arguments; review of arguments. These authors also suggest that the interactions between the students, with regard to criticism, may vary, as different are the forms of participation of the students in this type of dialogue interactions.

Even though Sandoval and collaborators (2019) do not use the terms 'criticism' and 'evaluation' in their study, they do suggest that changes in the classroom culture lead to social responsibility, as the criteria and standards for work are generated and refined by the students. In this regard, we can consider these 'criteria and standards' as ways of assessing and criticising the arguments and other stages of the process. These authors also suggest that these mechanisms of accountability and of location of authority (to whom the students direct themselves) are ways of expressing the distribution of the epistemic agency. This means that we can say that, both for González-Howard and for McNeill (2020) as also for Sandoval and collaborators (2019) the analysis of distribution 
of the epistemic agency are related to the practices of criticism and evaluation in the classroom.

Another aspect that favours occurrence of criticism and evaluation are the counterarguments, understood as objections to a given viewpoint or argument (Leitão, 2000). According to Leitão (2000), counterarguments can arise in different ways. For example, changing the focus of the argument (offering support to another side of the issue); and seeking to disregard an element from the argument concerned (merely denying or questioning the truth of a statement). This author also suggests that there are different responses to counterarguments. For example, the objections can be accepted, integrated (adaptation of the arguments to the criticism, qualifying it or providing additional evidence), localised (partial acceptance) or rejected (rejection of opposition to the argument, attacking the very declaration of opposition).

For these practices of criticism and evaluation to be part of the classroom culture, it is necessary that students understand that the objects of criticism are the ideas, rather than the people (Henderson et al., 2018); that they acknowledge the context as being argumentative and favourable to criticism (see, for example: Berland \& Hammer, 2012; González-Howard \& McNeill, 2020); and that they recognise the need to listen to others and take a position (González-Howard \& McNeill, 2020).

The third aspect of the construction of a classroom culture of argumentation is the temporal and processual dimension. Larraín and Freire (2011) state that learning of scientific argumentation occurs in a processual manner. According to these authors, the ability to build arguments, especially considering the ability to present opposing ideas, can be investigated even in children of a tender age. Therefore, the ability to understand the structure of arguments would take place at the final phases of this process. Moreore, it would be facilitated if, from early age, children were encouraged to defend their viewpoints and to critique opposing ideas.

This notion that changes in culture occur over time and events can also help to explain the results of the studies mentioned by Berland and Reiser (2011), which suggest that changes in the practices of different communities are not trivial. This non-triviality present in transformation of practices could be because these changes, according to Ethnography in Education, involve the renegotiation of standards and expectations constructed within the group over time and in events, requiring changes in the methods of interaction between members of the community (Green et al., 2005).

This temporal dimension could also explain changes in students' forms of participation when there are no changes in the questions teachers posed (McNeill \& Pimentel, 2010) or in the ways students interpret instructional contexts (Berland \& Hammer, 2012). In the study by McNeill and Pimentel (2010), for example, the main factor that contributed to increase interaction between students and the presence of counterarguments was that the teachers included more open questions, while in the study by Berland and Hammer (2012), the main factor that seemed to justify these changes was the fact that the students recognised instructional contexts as being argumentative. 
Therefore, when a longer period is considered for the analyses, it is possible to characterise the way in which the roles, constructed situationally based on actions and interactions, vary and change over time/in different situations; and how the ways in which knowledge and texts as generated in an event are connected, and become a resource for members' actions at subsequent events. In addition, the teacher's role in the process and the changes in the students' participations can be better understood.

The fourth aspect involved in the construction of a classroom of argumentation is diversity. There are many research studies that have not looked into argumentation from a cultural standpoint, but they evidenced that there are different ways of arguing, and that awareness of these differences may favour the inclusion of minority groups in Science Learning. In this regard, we infer that the construction of a culture of argumentation may occur in different ways.

In the study by Berland and Reiser (2011), for example, key elements of the scientific argumentation discourse made it possible to characterise the movement between goals of persuasion and goals of understanding ("sense-making"). However, engaging in persuasion and "sense-making" occurred differently in the two groups, representing different forms of scientific argumentation.

In the same direction, Baker (2015) highlighted the diversity of forms of argumentation on suggesting the existence of a wide range of dialogues that involve sharing arguments that are important for learning, but are not full declared conflicts.

In contrast, in the study by González-Howard and McNeill (2020), the authors showed evidence that there are many ways of criticising in argumentative situations. Some of these forms may not be accepted or recognised by the classroom community or not being aligned to the dominant forms of awareness, and explain the world. Thus, the authors suggest the need for awareness, valuing different ways of making science, and especially of argumentation in the classroom.

The need to be aware of other argumentation styles, and particularly those of minority groups, becomes more and more widely accepted in the field, in the light of cultural and linguistic diversity of the students, and the importance of ensuring participation (for example: González-Howard \& McNeill, 2020; Henderson et al., 2018). In this regard, the analysis of discursive interactions based on a cultural perspective can contribute to make this diversity more visible.

The fifth aspects related to the construction of a classroom of argumentation is the social and the collective dimension. As mentioned above, the group/collective is key to the definition of culture as shown by Sandoval and collaborators (2009). In this regard, Rudsberg et al. (2017), did not focus on culture, but evidenced, through discursive interactions, how students influence each other, making a contribution to argumentation and the collective construction of knowledge. Thus, the knowledge the group constructed influenced individual argumentation.

Sandoval and collaborators (2019), apart from accepting that the construction of meaning is inherently collective, suggest that the practices of argumentation need to 
be situated in wider knowledge production activities, and the students also need to see reasons for arguing. In this perspective, these practices result from seeking consensus about specific goals that are collectively shared. In addition, the teacher has an important role in helping the students to keep their focus on the main epistemic issues, and to get involved with each other's ideas in a productive and responsible way.

Other studies that do not analyse interactions in the classroom from a cultural viewpoint bring evidence to prove the centrality of this social dimension. For example, in the study of Berland and Hammer (2012), the engagement in argumentation was favoured when students recognised the context as being argumentative, and were stimulated by the teachers to challenge each other's ideas. In the case of McNeill and Pimentel (2010), more open questions asked by the teacher favoured greater interaction between students, who would then share their ideas more, clarifying their own way of reasoning and connecting ideas with colleagues.

Ferraz and Sasseron (2017) also broadened our understanding about the influence of teacher actions upon the students' argumentation. They concluded that the way the teacher has problematised the subject matter knowledge to be understood has had a direct influence upon students' talk and production. Their analysis of actions of this teacher, based on an instrument that the authors themselves have devised, allowed the characterisation of how the teacher can favour the argumentation of students in investigative contexts, with the presentation of his epistemic purposes and typical actions related to each purpose. For example, the category of proposal "Problematising" corresponds to actions that make the object of study suitable for investigation by the students" (page 48). The typical actions related to this category are those to propose a problem or transform a situation or doubt into a problem that the group could investigate.

Another instrument for analysis of teacher actions in favour of argumentation was devised by Ibraim and Justi (2018) based on references and on the professional practice of a teacher. In this case, actions are understood as being one of the essential elements of the set of awarenesses for the teaching action in argumentation. This knowledge makes it possible to "teach Science involving argumentation" (page 315) and "engage students in experiencing and in thinking about this scientific practice" (page 315). Out of the eighteen teacher actions, we can mention, for example, "encourage the students to take part in the debate, and express their own ideas" and "present arguments that challenge students' ideas" (page 319).

Understanding that argumentation is an essential element in the collective construction of knowledge, Larraín and Freire (2011) characterise teacher actions from a perspective that gives greater importance to the issue of discourse. These actions can either encourage or inhibit students' argumentation, right from the initial stages of schooling. For example: 'recognise controversy and elaborate it clearly and explicitly, so that the whole group may perceive it and think about it, and thus benefit from the dialectic movement the peer started" (page 73). In addition, the authors show evidence that the students, from when they are very young, are able to establish ideas, and that 
their participation in situations involving solution of disagreements are the starting point for constructing understandings about the structural aspect of argumentation.

\section{Notions of culture and argumentation that guide the theoretical and methodological references of the study}

The definition of culture of argumentation as presented by Sandoval and collaborators (2019) has commonalities with the definition of culture from Ethnography in Education, which informed our study. This approximation is the result of the recognition of the importance of language and of the group, for the construction of culture. Therefore, the analysis of discoursive interactions becomes essential to understand the culture of argumentation of a classroom.

In the perspective of Ethnography in Education, culture is "a set of principles involving practices constructed by its members with the establishment of roles and relations, standards and expectations, and rights and duties that are part of the feeling of belonging to the local group" (Spradley, 1998 cited by Green et al., 2005, page 30). To investigate a culture, we need to "focus on understanding what members of a classroom need to know, do, predict and interpret in order to participate in the construction of ongoing events through which cultural and subject matter knowledge of that classroom are developed" (Rex, 2006, page 4). In the present study, we use this definition of classroom culture from Ethnography in Education to analyse how a culture of argumentation can be constructed.

Green, Dixon and Zaharlick (2005) suggest that this concept of culture is not fixed, as standards of living are constructed to the extent that teachers and students act and interact through discourse, over time and during events. In addition, standards and expectations are set, contested and redefined, whether implicitly or explicitly (see, for example, Dixon \& Green, 2005; McDonald \& Kelly, 2012). This means that we need to pay attention to these aspects in order to understand changes in culture and in argumentative processes.

Green, Dixon and Zaharlick (2005) also stress that the basic analytical unit of classroom ethnography is the group, and not the individual. It is also understood that teachers' and students' actions are shaped by the other students' responses (verbal or non-verbal) in the classroom (Dixon \& Green, 2005). In this regard, we can say that the members of a classroom have mutual influences on each other, and the actions of each member contributes to establish a direction for discourse. In addition, these different ways of acting and reacting to each other, also constitute the different paths the members of a classroom took, and can lead to different ways of constructing a culture of argumentation.

Beyond explicitly stating which definition of culture informed this study, it is important to present the concept of argumentation that guided the present research, as well as, justify this choice. In the field of Science Education research, argumentation/the argument have received many different definitions. In this way, it can be understood as a 
declaration and as a process. Depending on the study, argumentation can be understood as being related to contexts of dialogue, or as occurring internally in the person's mind (or both). In this regard, in some cases, it is understood that argumentation/argument can be constructed socially or produced individually. Other authors present a concept more centred on the justification of knowledge, and others on persuasion (JiménezAleixandre \& Erduran, 2007).

There are also perspectives that argumentation/an argument is conflict, where two or more people have opposite points of view and are responsible for defending the respective points of view (Jiménez-Aleixandre \& Erduran, 2007; van Eemeren, et al., 2002) or can be doubt, uncertainty, or questioning of a certain viewpoint or argument (van Eemeren et al., 2002). Some researchers choose one of these viewpoints, while others combine several of them (Jiménez-Aleixandre \& Erduran, 2007).

In the case participants in the present study, there was no formal phenomenon by the name of "argumentation". Thus our analysis was informed by the notion that when members of the group do not have a "name" for their activities, then the researchers may "make decisions based on theoretical principles" (Green, Dixon, \& Zaharlick, 2005, p. 45). Due to these characteristic of the research context, it was important that we adopted an argumentation theory that could provide, at most, the understanding of the events based on the emic perspective (of the participants), which is a key principle of Ethnography in Education. In the Pragma-Dialectics theory of argumentation, we have found significant potential, mainly with regard to the very concept of argumentation, the metatheoretical assumptions, and the descriptive tools of this theory.

According to van Eemeren, Grootendorst and Henkemans (2002, page xii), "argumentation is a verbal, social, and rational activity aimed at convincing a reasonable critic of the acceptability of a standpoint by putting forward a constellation of one or more propositions to justify this standpoint".

This concept harks back to the metatheoretical assumptions of this theory that could be related to Ethnography in Education. For example, this theory, as also Ethnography in Education, recognises that, when people make use of the language, they are doing something. In addition, as argumentation is understood as a social activity, the focus of the analysis is the group rather than the individual (see Eeemerenet al., 2002; Castanheira et al., 2007).

The rational dimension is linked to variations of rationality and acceptability of proposals and arguments, as they depend on what the reader or listener legitimates/ validates and on what is appropriate for the process of solution of each difference of opinion (van Eemeren \& Grootendorst, 2004). These variations, both in terms of rationality and acceptability, are highly relevant for the study of argumentation based on an ethnographic perspective, as they enable the characterisation of argumentative situations based on an emic perspective (of the participants) of diverse groups, while respecting the specificities of each group (see Green et al., 2005).

Within this concept, we can also see that van Eemeren, Grootendorst e Henkemans 
(2002) suggest that the role of argumentation is that of solving differences of opinion. According to this theory, the difference of opinion arises when someone presents a point of view and then the other people - either real or projected people - submit this point of view to questions, doubts, objections, or counterarguments (see in van Eemeren et al., 2002). In this regard, what counts as argumentation goes well beyond the concept of conflict, widely used in the field of Science Education (Jiménez-Aleixandre \& Erduran, 2007).

In Pragma-dialectics, therefore, two or more people may have opposing views, as also may come up with doubts, uncertainties, and questions about a specific point of view. This aspect is relevant, when we take up an ethnographic perspective. This is because, when we broaden the notion of argumentative situation, we can also identify and characterise the argumentation that occurs in minority social groups and/or groups that communicate mainly in an indirect or implicit manner.

Thus, when we refer, throughout the text, to terms such as "controversy", "disagreement" or "difference of opinion", we are considering both situations of conflict and those that involve doubts, questions and uncertainties. In addition, based on the perspective of Pragma-Dialectics theory of argumentation, both the counterarguments and response of rejection as proposed by Leitão (2000) are analysed as antagonistic positions, as these are situations where the participants raise doubts about, or object to, points of view or arguments.

\section{Methodology}

The study was carried out in two different educational scenarios, in a capital city of the Southeast Region of Brazil ${ }^{1}$, thereby strengthening the occurrence of many processes for the construction of a culture of argumentation. The first was a Science classroom for adult education classes (EJA) in the night shift of a federal school. When we started data collection (2009), this group was in the first year of a outreach education Project of a state-owned University, seeking to allow completion of the final years of Middle School. The classroom group had 25 students ( 6 men and 19 women) aged over 45 . The teacher, Domingos ${ }^{2}$, graduated as a teacher of Biological Sciences while the data was being collected, but had two years of prior experience. His lessons were predominantly based on dialogic lectures. However, there was a lot of interaction, mainly encouraging the students to take part, and asking questions to assess understanding.

The second scenario was a Year 8 Science class of a regular course at a municipal school. Here the class group had 30 pupils (12 boys and 18 girls) aged between 13 and 15. Beatriz, the teacher, had been teaching this class group since the previous year and

1 The "Cases" presented in this research study involved the participation of students and teachers. Even though these research studies bring a minimum of risk to participants and their institutions, we have followed the standards and guidelines as established by Ruling No. 196/96 of the National Health Council (CNS), with approval from the Research Ethics Committee of the Federal University of Minas Gerais, under statement numbers ETIC 0472.0.203.000-09 (master's degree research) and ETIC 0239.0.203.000-11 (doctoral research).

2 All names are pseudonyms, in order to protect the anonymity of the participants in the survey. 
had a teaching degree in Biological Science and a master's degree in Education. In the year when data was collected (2011), she had seven years of experience as a teacher. Her lessons were also predominantly based on dialogic lectures, with plenty of interaction, but also including reading, problem solving, and laboratory activities. ${ }^{3}$

\section{Research design, data construction, and analysis procedures}

A naturalist perspective of qualitative research guided this investigation (Lincoln \& Gubba, 1985). The study can be characterised as a multiple case study of a more instrumental nature (Stake, 1998), informed by Interactional Ethnography (Castanheira et al., 2007; Dixon \& Green, 2005; Green et al., 2005).

The first author carried out participant observation (Spradley, 1980) with records in field notes, combined with audio and video records (Skukauskaité et al., 2007) for a period of eight months in the adult education (EJA) classroom (2009-2010) and ten months in the Year 8 classroom (2011).

Initially, macroscopic analyses were carried out, for each class group separately, involving the construction of event maps and timelines with different levels of detail (for example, as in Dixon \& Green, 2005). Through these analyses, it was possible to identify key events involving argumentation, with regard to learning of concepts, practices and discourse related to different topics addressed in the lessons (e.g., Duschl, 2008). These events, as argumentative situations, were considered more significant for the research participants. The criteria adopted for selection were the following: i) the participation of many participants in solving a difference of opinion; ii) a participation time of more than five minutes.

The three events in the EJA group and the two events in the Year 8 class (with durations between 5 and 30 minutes) were transcribed verbatim (Bloome et al., 2005) and analysed separately. In other words, we look at the similarities and the differences between the argumentative situations of each of the class groups, seeking to understand the argumentative processes in this group. Only after we understand the processes in each group do we contrast the events of both groups to analyse similarities and differences, asking ourselves how these processes contribute to the construction of a culture favourable to argumentation.

Initially, the transcriptions were analysed with the main reference being the descriptive dimension of the Pragma-Dialectics theory of argumentation (van Eemeren, Grootendorst, \& Henkemans, 2002). In Pragma-dialectics these descriptive tools are used to evaluate argumentative discourse, considering what specialised authors call critical discussion. In this study, on the other hand, we do not have the goal of evaluating discourse, but rather increase the visibility of argumentative processes and of the construction of a classroom culture of argumentation, through interactive discourse. In this regard, these descriptive tools were adapted considering aspects from Ethnography

3 In previous work, we have investigated argumentative processes in the Adult Education (EJA) classroom (Munford \& Teles, 2015) and in Year 8 classes of regular schooling (Munford \& Teles, 2013) separately. Therefore, in this work, we present more details about each class and about how argumentative processes were developed. 
in Education and characteristics of a culture of argumentation, as mentioned above.

In our analyses, therefore, we seek to describe: i) when, how and by whom the disagreements were generated; ii) which elements were implicit or explicit; and iii) the process for solving disagreements, considering: a) how the members of the group stood and interacted through discourse to defend their points of view and arguments (protagonist) and/or to bring doubts, uncertainties, or opposing positions to some point of view or argument (antagonist); and v) how, in these discursive interactions, wider disagreements (main difference of opinion) were solved based on more specific disagreements (subordinate difference of opinion).

During the analyses, we have prepared charts that allow the establishment of a link between discourse interaction and analyses, based on the categories mentioned above (Figure 1). These charts have mapped the whole argumentative process for each event. Based on the information contained in these charts, we have constructed syntheses for each category of analysis, and then contrasted these syntheses with those of other events involving the same class, in order to understand the argumentative processes of each classroom (Munford \& Teles, 2015; Munford \& Teles, 2013). In this study, we contrast the elements of the two class groups, seeking to identify similarities and differences between the argumentative processes and their relation to the construction of a culture of argumentation.

Figure 1. Section of the Chart that links discourse and analyses based on Pragma-dialectics and their respective adaptations

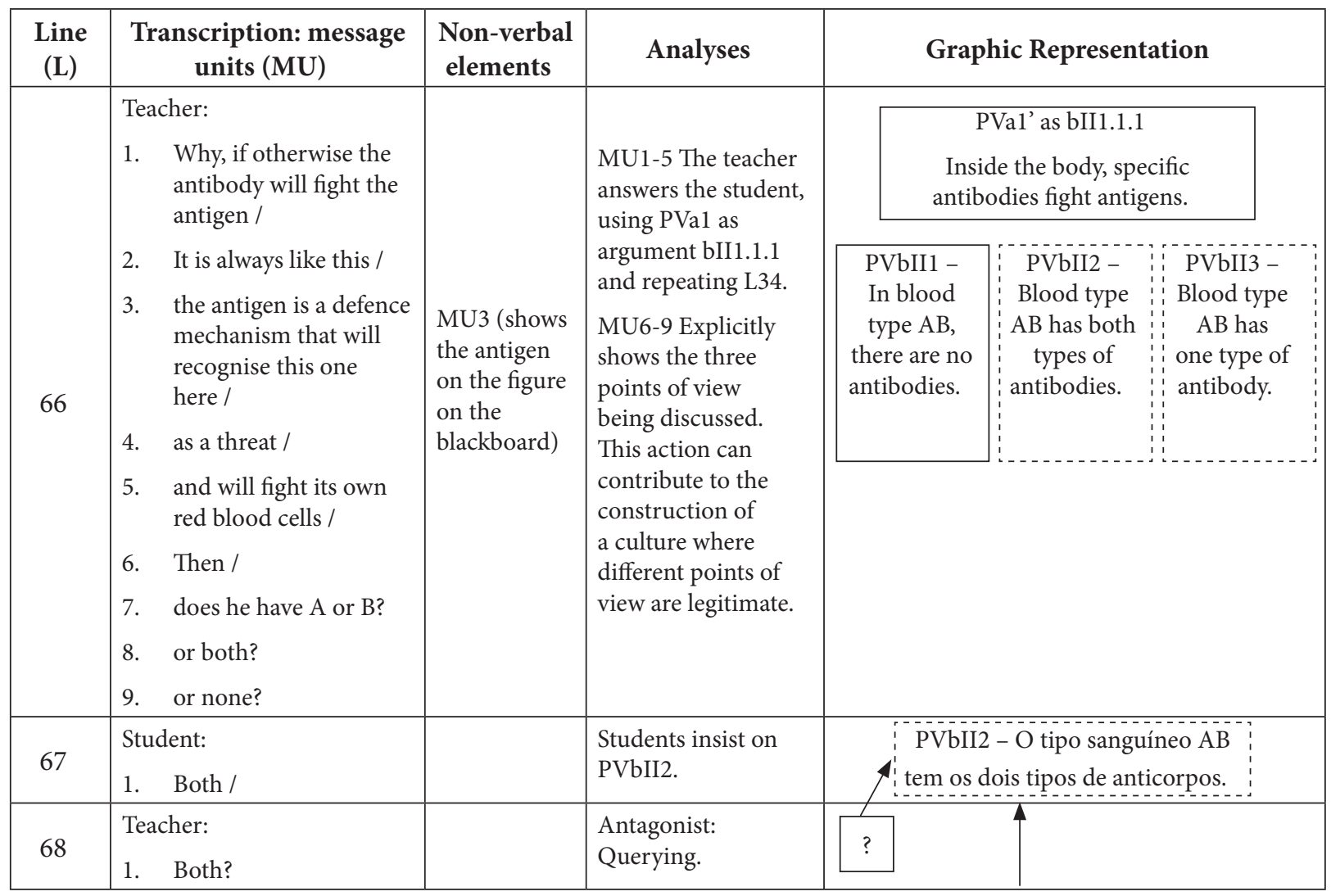


This section (Figure 1) corresponds to the lesson about the ABO blood grouping system, of the EJA class. In the first column, we insert the number of the Line (L), which corresponds to the changes of speaker, throughout the interaction. In this example, we show the section of transcription from L66-0L68, which means that there are 65 lines of discursive interactions before those represented. ${ }^{4}$ In the last column, we try to present a graphical representation of the analyses described in the previous column, showing the articulation between the different elements of argumentation. PVal' = 1st point of view of subordinate difference of opinion 'a'; bII1.1.1 = subargument 1.1.1 of difference of opinion 'bII'; PVal' as bII1.1.1 = content of argument bII1.1.1 is the same as PVal'; PVbII1 = 1st point of view of the 2nd subordinated difference of opinion 'bII'; PVbII2 $=2^{\text {nd }}$ point of view of the $2^{\text {nd }}$ subordinated difference of opinion ' $b I I$ '; PVbII $3=3^{\text {rd }}$ point of view of the $2^{\text {nd }}$ subordinated difference of opinion 'bII'; PVa2' as bII2.1.1 = content of the argument bII2.1.1 is the same as PVa2'; the apostrophe means that the element is implicit in the discourse, as in PVal'.

\section{Results - Contrast between argumentative processes}

As mentioned previously, the argumentative processes corresponding to each class group separately were published in other academic papers (as mentioned in footnote 3 ). In the present study, we contrasted all the events in both groups, seeking to answer our research questions. In this section, we organise the contrasts based on the descriptive tools from Pragma-dialectics as mentioned above, seeking to answer our first question: "In what aspects are the argumentative processes in a Year 8 class of regular education and Adult Education (EJA) the same, and in what aspects are they different?"

In Figures 2 and 3, we have situated the events on a timeline and presented a summary of the events selected, respectively, from Science lessons in EJA and in Year 8 of regular school.

4 To facilitate the identification of the moment of the class history to which the transcribed excerpts refer, we have numbered the lines in one single numerical sequence, meaning that the first line of events in the second line corresponds to the sequence of the last line of the events of the first lesson, and so on in succession. However, it is very important to highlight that, as shown in Figure 2 and Figure 3, these events did not occur immediately following each other. 
Figure 2. Timeline with general characterisation of the lessons of the EJA group

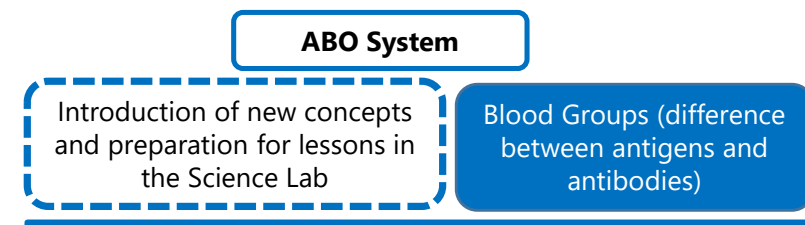

The teacher constructed a table on the blackboard, depicting the $A B O$ blood grouping system, and drew a red blood cell with antigens and two types of antibodies that could be found in plasma.

On filling in the parts of the table corresponding to A and $B$ blood types, and together with the students, the teacher constructed common knowledge about the relationship between antigens and antibodies.

The filling-in of the parts of the table related to the $A B$ and $O$ blood groups, and discussions about blood transfusions, led to the disagreements analysed. These disagreements were permeated by a wider and implicit disagreement, with regard to different forms of interaction with the table.

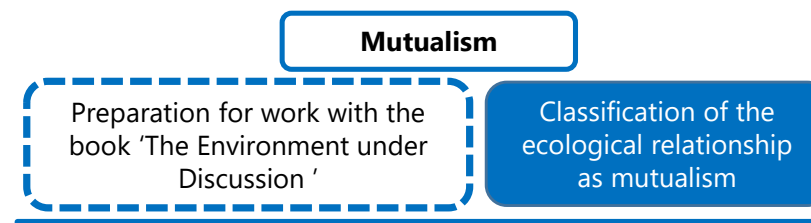

The teacher revised the concepts as addressed in the previous lessons, including the ecological relations of 'Mutualism' and 'Protocooperation'. After explicitly constructing common knowledge, the teacher asked the students to provide an example of mutualism.

One student suggested the interaction between the crocodile bird (Pluvianus aegyptus) and crocodiles themselves. In response, the teacher problematised this response, encouraging students to think, and this led to a difference of opinion about whether this relationship was mandatory or not.

This was permeated by a wider and implicit disagreement as to whether this example can be considered an example of mutualism or not.

\begin{tabular}{|l|c|c|c|}
\hline & YEAR 2 & \\
\hline MAR & APR & MAY & JNE \\
\hline Investigative Unit & & JLY \\
\hline
\end{tabular}

The teacher read the outline of activities of investigation of solid residues as far as the 'Methodology' section. On the blackboard, he drew a table (with the columns DATE, OBJECT, QUANTITY and MATERIAL), to show the students how to fill it in.

In this filling-in process, a disagreement arose, involving two aspects or two propositions (whether to measure objects or materials; whether to use conventional units of measurement or not).

This was permeated by a wider disagreement based on 'What does it mean to use a unit of measurement?' This issue was not addressed directly, meaning that it was implicit in the participants' discourse.

The square with dotted sides brings information about the instructional context in which the argumentative situation is inserted. The blue square shows the main issues involving argumentation. 
Figure 3. Timeline with the general characterisation of the lessons in Year 8

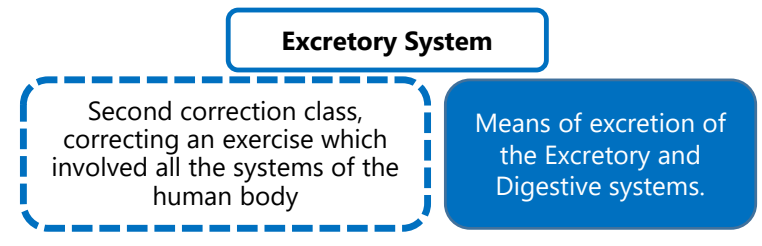

The exercise consisted of identification of the system of the human body corresponding to each figure. On identifying the figure showing the Excretory system, together with the students, the teacher asked a question about the function of the system, as there was no engagement.

To solve this wide disagreement, she proposed a more specific question about the difference of what is eliminated in the faeces and what is eliminated through the urine.

Through questioning, the teacher helped the students to construct their own points of view and arguments, implicitly setting some rules so that the points of view and arguments of the students were accepted based on the perspective of School Science. At the end of the lesson, the teacher showed her point of view, and her arguments, following the rules as previously set.

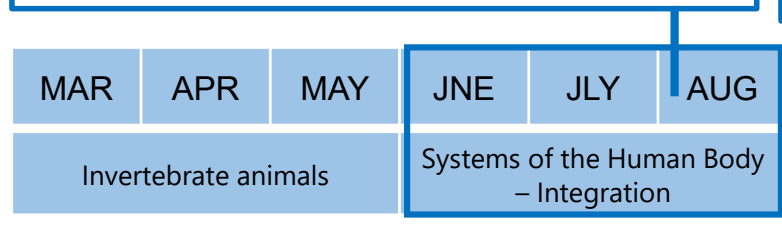

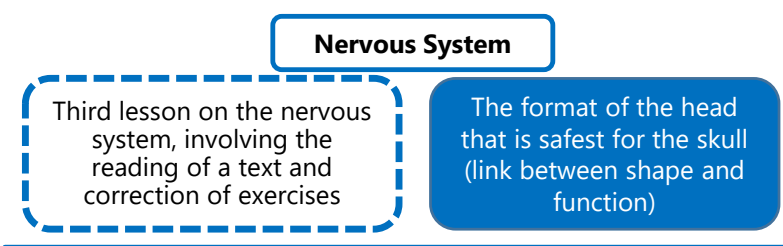

The teacher problematised a piece of information in the text, about the oval shape of the human skull being safer than other shapes. She suggested that the students imagine a hypothetical situation in which the format of the human skull was rectangular or in the shape of a lozenge.

As the students were involved in the consideration and thought about the hypothetical situation, there was disagreement. During the process to solve the disagreement, the teacher explicitly set some norms, and problematised the answers raised by the students, inviting others to participate in the discussion.

This disagreement involved a wider and implicit difference of opinion about whether a spherical form for the skull would or would not be better than other geometric shapes. At the end of the lesson, the teacher made a synthesis to answer the question, using the contributions that the students had made.

\begin{tabular}{|c|c|c|c|c|c|}
\hline AUG & SEP & SEP & OCT & NOV & DEC \\
\hline $\begin{array}{r}\text { Cyto } \\
\text { His }\end{array}$ & $\begin{array}{l}\text { y and } \\
\text { ogy }\end{array}$ & $\begin{array}{l}\text { Nervous } \\
\text { System }\end{array}$ & \multicolumn{3}{|c|}{ Sensory System } \\
\hline
\end{tabular}

The square with the dotted line brings information about the instructional context in which the argumentative situation finds itself. The blue square shows the main theme involved in the argumentation.

\section{Causing disagreements}

As we can see from Figures 2 and 3, we can observe when, or in which context, disagreements arose in each classroom. In the Year 8 group (Figure 2), the class disagreements about the Excretory System arose during the correction of exercises, while in the case of the Nervous System, they appeared after the collective reading of a didactic text about the issue. In the EJA group (Figure 3), on the other hand, disagreements came about during the introduction of new concepts in the lesson on the $\mathrm{ABO}$ blood grouping system, during a discussion of questions concerning how to complete an investigation worksheet on domestic waste, in the lesson on Solid Waste. In the lesson on mutualism, on the other hand, disagreements arose when they were studying concepts related to 
ecological relations, preparing for the presentation about a paradidactic book about the environment.

With the exception of the lesson on Solid Residue, which had more of an investigative approach to it, in all the other lessons the situations where argumentation occurred were mainly those where there was discussion of conceptual aspects, without much room for changes of position, based on the perspective of Science Education.

Based on the descriptive tools of Pragma-dialectics, under the guidance of an ethnographic perspective, it is also important to observe not only when, but also how and by whom the disagreements came about. In both the classrooms investigated, in all events, it was the teachers who started the disagreements (Figure 4).

Figure 4. Contrast of how disagreements came about in argumentation events, in both scenarios

\begin{tabular}{|c|c|c|c|c|}
\hline \multicolumn{3}{|c|}{ Events of the EJA Group } & \multicolumn{2}{|c|}{ Events of Year 8} \\
\hline ABO System & Solid Residue & Mutualism & Excretory System & Nervous System \\
\hline $\begin{array}{l}\text { Teacher }(\mathrm{T}) \text { queried } \\
\text { the students' (S) } \\
\text { answers about } \\
\text { concepts not yet } \\
\text { addressed in the } \\
\text { classroom: antigens } \\
\text { and antibodies. }\end{array}$ & $\begin{array}{l}\text { T queried the } \\
\text { methods of } \\
\text { measurement of } \\
\text { organic matter, } \\
\text { of the Ss. }\end{array}$ & $\begin{array}{l}\text { T queried an } \\
\text { example of } \\
\text { Mutualism } \\
\text { that an S } \\
\text { had given. }\end{array}$ & $\begin{array}{l}\text { T questioned an } \\
\text { answer about the } \\
\text { System that an } \mathrm{S} \text { had } \\
\text { given, with regard } \\
\text { to an issue that had } \\
\text { already been addressed } \\
\text { in the classroom. }\end{array}$ & $\begin{array}{l}\text { T proposed a } \\
\text { hypothetical } \\
\text { solution with } \\
\text { regard to the shape } \\
\text { of the human } \\
\text { skull. }\end{array}$ \\
\hline
\end{tabular}

$\mathrm{T}=$ teacher; $\mathrm{S}=$ student $(\mathrm{s})$.

In Figure 4, we can also get some idea of how disagreements started. In the EJA class group, all disagreements started with the teacher's questioning. In contrast, in the Year 8 group, both the teacher's questioning and the proposal of a hypothetical situation led to disagreements.

In Figure 5, we can see that the starting point for the construction of the disagreement was the hypothetical situation the teacher proposed, in the lesson on the Nervous System, based on the problematisation of information contained in the textbook. At L126, in italics, the teacher proposes the hypothetical situation. The student Joanna made a comment (L127) and then the teacher called the attention of the class to the reasoning this student had used, implicitly asking her to explain her idea to the class (in italics L128). The student then repeated what she said. Replacing there would be no problem' with 'it would be safer' (L129). The teacher then questioned this position the student took, and invited other students to state their views (L130). As many students said they disagreed (L131), the process of solution of this disagreement got under way. 
Figure 5. An excerpt from the lesson on the Nervous System - Year 8 group

\begin{tabular}{|c|c|}
\hline Line $(\mathrm{L})$ & Discursive interactions \\
\hline 126 & $\begin{array}{l}\text { Teacher: the skull / the bones of the skull / that are hard and fit perfectly, forming this ball/ } \\
\text { this rounded structure which is our head / Here in the text / it says that one of the strongest } \\
\text { shapes we know is that of a rigid ball / So / you could think like this / (the students talk } \\
\text { among themselves) if you are foolish / you will make somewhat senseless comments / } \\
\text { but just look at why? / Imagine that our head /instead of being of this shape, / if it were a } \\
\text { square, or a rectangle or a lozenge / the shape of a box / How nice it is that no-one is foolish } \\
\text { here / because in the other class / I went and said that / and everyone saying / 'oh, how } \\
\text { weird! Wow!' / But you need to think of the following / if everyone had a square head / the } \\
\text { standard would be different / it would be normal to have a square head / Imagine all of us } \\
\text { with square heads / and then, one day, I could come over and say / "So, guys, / imagine if } \\
\text { we all had rounded heads / My goodness / we would be really ugly" (laughs) / For people / } \\
\text { this is the normal appearance / the rounded head / }\end{array}$ \\
\hline 127 & $\begin{array}{l}\text { Joanna: At least / if we had square heads / there would not be so many problems / because } \\
\text { when we fell over / we would be straight / }\end{array}$ \\
\hline 128 & $\begin{array}{l}\text { Teacher: Here / Joanna was saying the following / Fabrice / turn round please / if not I will } \\
\text { put you back there / Come on / (the teacher turned back and faced the students) / She } \\
\text { defended the following view / that if we had square heads, / then, were we to fall / what would } \\
\text { happen? }\end{array}$ \\
\hline 129 & Joanna: We would be straight / instead of (inaudible) / It would be safer / \\
\hline 130 & Teacher: Safer? / So / it would be smarter / to have a square head? Does anyone disagree? / \\
\hline 131 & Several Students: I disagree / \\
\hline
\end{tabular}

In the other lessons, we see that both teachers have queried students' answers or proposals. Based on an ethical perspective (a perspective from someone who is not a member of the group) these queries could correspond to demand for deeper understanding. However, we have analysed the questions asked by teachers and also subsequent actions of the members of each class group, seeking to take in the perspective of the participants, as recommended by Ethnography in Education (for example, in Green et al., 2005; Rex, 2006). In this way, we notice that the questions, for each group, are queries, as they result from differences of opinion in which the group has engaged to solve them, thus being established as a situation of argumentation, as proposed in the Pragma-dialectic theory (see van Eemeren et al., 2002).

As an example of such queries we have presented the lesson on the ABO blood grouping system, in the EJA class group. In this lesson, the teacher was introducing knowledge about the interaction between antigens and antibodies, with regard to the blood groups of this system; in other words, it was a moment when the students had their first contact with that particular unit of knowledge. The teacher requested the participation of the class group for filling in a table with information related to these blood groups. The disagreement arose when the teacher asked the students about the antibodies of blood group AB (in italics in L54, Figure 6) and the students answered A and B, directly (L55 and L58) or indirectly (L57). The teacher questioned this answer (L59). 
The question from the student Gabriella (L60) and the teacher's question raised (L61), requesting additional explanations about what the student meant to say, are additional evidence that the disagreement was strongly linked to knowledge of different ways of communication within the field of Natural Science, in a way that is articulated to the domain of conceptual knowledge. Reading and completing a table is an action informed by standards constructed based on participation in social practices within a certain community.

For the teacher, such practices have come from Academic Science and were 'moved' to the school context: the table represented phenomena (L54 and L59) and was used to 'talk about Science.' For the students, the table was a 'school' object, meaning that it was not contextualised in practices and discourses of the realm of Science. As shown by the words of Gabriella (L60), there was a rule that was followed, stating that if anti-A occurs with $B$, and anti-B with $A$, then anti-A and anti-B shall be present with $A B$ '

Figure 6. An excerpt of the lesson on the ABO blood grouping system - EJA class group

\begin{tabular}{|l|l|}
\hline 54 & $\begin{array}{l}\text { Teacher: It has both / shall put the subtitles here / there is antigen A / that is the ball / and then } \\
\text { we have antigen B / that is the triangle / And the antibody shall then fight the antigen / Won't } \\
\text { it connect to the antigen over there? / Won't it have the specific tip to connect to the antigen? } \\
\text { / And we have these two types of antibodies / anti-B and anti-A / Could it be that anyone with } \\
\text { blood group AB -, what kind of antibody will this person bring in this person's plasma? / }\end{array}$ \\
\hline 55 & Bianca: O A and B / \\
\hline 56 & Professor: ah / \\
\hline 57 & Margaret: It's not both of them, right? / \\
\hline 58 & Erika: This person will have antibodies A and B / \\
\hline 59 & $\begin{array}{l}\text { Teacher: Antibodies A and B? / But there / just look / if the person has antibody A and antibody } \\
\text { B, if the person's blood is like this / Don't draw / now just pay attention here / It is like this / } \\
\text { person's red blood cells / and will recognise the person's own red blood cells as a threat / It will } \\
\text { destroy / }\end{array}$ \\
\hline 60 & Gabriella: So does it always have to be the opposite? / \\
\hline 61 & Teacher: What do you mean, the opposite? / So which antibody will there be in the plasma? / \\
\hline
\end{tabular}

In a nutshell, we can say that disagreements came about in predominantly curricular contexts, where the concepts were of more central importance. In addition, the actions of the teachers, whether through questioning or by proposing a hypothetical situation, were of central importance so that the disagreements could start. As mentioned above, these situations were established as disagreements due to the involvement of the members of each group in the processes for solving these differences of opinion. These processes shall be described in the following sections. 


\section{Processes for solution of disagreements: Relations between differences of opinion}

After the disagreements start, in a procedural and diversified manner, teachers and students would interact through discourse, seeking to solve these problems ${ }^{5}$. In this section, we shall look at these processes in a more panoramic manner, considering the relationships between the differences of opinion.

In the lesson about the $\mathrm{ABO}$ system (EJA), for example, the process of solution of disagreements was different from those of all other processes (Figure 7). In this lesson, teacher and students did not mention, in their discourse interaction, the main disagreement regarding differences in ways of interpreting the table. This means that four more specific (subordinate) explicit disagreements were started, one related to the antibodies present in people with the $\mathrm{AB}$ blood group (as mentioned above) and three concerning blood transfusions, especially those for people with blood group $\mathrm{O}$.

In the other lessons, on the other hand, there was a main difference in the opinion, which was made evident in the discursive interactions in the lessons about Mutualism (EJA) and Excretory System (Year 8), and were implicit in the lessons on Solid Residue (EJA) and the Nervous System (Year 8). Seeking to solve the widest disagreement, more specific differences of opinion came about and these, in all lessons, were made explicit in the discursive interactions.

Figure 7. Contrast of the relationships between main and subordinate differences of opinion

\begin{tabular}{|l|l|l|l|l|}
\hline \multicolumn{3}{|c|}{ EJA Class } & \multicolumn{2}{c|}{ Year 8 Class } \\
\hline ABO System & Solid Residues & Mutualism & Excretory System & Nervous System \\
\hline
\end{tabular}

DO $\mathbf{p}=$ main difference of opinion; DO $\mathbf{s}=$ subordinate difference of opinion.

These results, therefore, show that there is no one single and universal, fixed, preset way of solving differences of opinion. There are situations in which the difference of opinion is not given and/or is not visualised by the participants (possibly up to the moment of taking up a position) and contrast of ideas allows one to become aware of the differences of opinion (lesson on the $\mathrm{ABO}$ blood grouping system). In other situations, the teacher intentionally presented the differences of opinion, as a way of promoting learning. In the next section, we shall present further evidence of this diversity, highlighting positions and interaction between members of the group.

5 We consider that the disagreements were solved when the participants ceased to get involved in the process, regardless of whether there is a consensus or not. 


\section{Processes of solution of disagreements: Position and interaction}

In this section, we shall describe the process for solution of disagreement, considered as when members of the group take positions and interact through discourse to defend their viewpoints and arguments (protagonist) and/or to raise doubts, uncertainties, objections, or counterpositions to some standpoint or argument (antagonist). Initially, in a panoramic view, we contrast two classrooms, with regard to teachers, and then two classrooms, with regard to the students. Later, we present excerpts of discursive interactions to present examples of some aspects of the process of solution of disagreements.

As discussed before, disagreements arose mainly due to the actions of the teachers. They have also had a key role in the process of solution of differences of opinion. However, the methods of student participation have also contributed significantly, by increasing the diversity of argumentative processes.

On contrasting all the events, considering the positions and methods of interaction of the teachers (Figure 8), we can see, in this panoramic perspective, that the teachers have acted both to defend their own points of view (protagonists) as also acted as antagonists, mainly through questions. These questions have made it possible for teachers to maintain their implicit positioning ${ }^{6}$ for much of the event, and were also important to promote student participation in different ways.

Figure 8. Contrast of the opinions, and means of interaction of the teacher, in both scenarios

\begin{tabular}{|l|l|l|l|l|}
\hline \multicolumn{3}{|c|}{ Events of the EJA Group } & \multicolumn{2}{c|}{ Events in Year 8 } \\
\hline ABO System & Solid Residue & Mutualism & \multicolumn{1}{|c|}{ Excretory System } & Nervous System \\
\hline $\begin{array}{l}\text { T acted as a } \\
\text { protagonist } \\
\text { and as an } \\
\text { antagonist, } \\
\text { especially in } \\
\text { an implicit } \\
\text { way, through } \\
\text { questions. }\end{array}$ & $\begin{array}{l}\text { T acted as a } \\
\text { protagonist } \\
\text { (for multiple } \\
\text { points of view), } \\
\text { in an explicit } \\
\text { manner, and as } \\
\text { an antagonist } \\
\text { in relation to } \\
\text { the opinions }\end{array}$ & $\begin{array}{l}\text { T acted as a } \\
\text { protagonist } \\
\text { and as an } \\
\text { antagonist, } \\
\text { implicitly, } \\
\text { through }\end{array}$ & $\begin{array}{l}\text { T invited the students } \\
\text { to take up a position } \\
\text { and then implicitly } \\
\text { proposed standards for } \\
\text { argumentation. T acted } \\
\text { as a protagonist and } \\
\text { antagonist, in an implicit } \\
\text { students upheld. T presented T's point } \\
\text { of view explicitly at the } \\
\text { end of the interaction, } \\
\text { complying with the } \\
\text { standards as established. }\end{array}$ & $\begin{array}{l}\text { Ts questioned the } \\
\text { set rules for } \\
\text { argumentation. } \\
\text { T presented his/ } \\
\text { her point of view } \\
\text { at the end of } \\
\text { the interaction, } \\
\text { thus presenting } \\
\text { a synthesis of } \\
\text { arguments and } \\
\text { counterarguments } \\
\text { the students made. }\end{array}$ \\
\hline
\end{tabular}

$\mathbf{T}=$ teacher $\mathbf{S}=$ students.

Apart from these common aspects, we can see some specific features. In the EJA lessons on Solid Residue and Mutualism, even when the positions and arguments of the teacher were explicitly stated, the disagreements continued while, in the case of the

6 We understand implicit positioning as occurring when the teacher or student questions bring elements of their positioning. 
lessons on the ABO blood grouping system (EJA), Excretory system (Year 8) and Nervous System (Year 8), the disagreements were solved after the positions and arguments of the teachers were made explicit. In the Year 8 class, the teacher also set some standards for argumentation, which were implicit in the lesson about the Excretory System, and were complied with when the teacher showed her opinion and arguments. In the lesson on the Nervous System, on the other hand, these standards were explicit, and the standpoint of the teacher was but a synthesis of the positions and arguments that the students had presented throughout the discussion.

With regard to the positions and interactions of the students, in a panoramic outlook (Figure 9), we see that, in both class groups, the students were responsive to questioning of the teacher and acted in the role of protagonists, using mainly experiences of daily life to construct their arguments. However, the students were also antagonists when they interacted more with their peers and/or presented scientific knowledge/ information from a textbook.

Figure 9. Contrast of the positioning and methods of interaction of the students in both scenarios.

\begin{tabular}{|c|c|c|c|c|}
\hline \multicolumn{3}{|c|}{ Events of the EJA Group } & \multicolumn{2}{|c|}{ Events in Year 8} \\
\hline ABO System & Solid Residue & Mutualism & Excretory System & Nervous System \\
\hline \begin{tabular}{|l} 
S were \\
responsive \\
to T. They \\
interacted \\
mainly with \\
T. They acted \\
in the role of \\
protagonists, \\
implicitly \\
taking up \\
positions, and \\
interpreting \\
the table \\
based on \\
syllogisms.
\end{tabular} & $\begin{array}{l}\text { S were responsive to the } \\
\text { questions raised by T. } \\
\text { They acted with other } \\
\text { Ss and with T. Many } \\
\text { different interactions: } \\
\text { points of view without } \\
\text { arguments, points of } \\
\text { view trying to conciliate } \\
\text { other viewpoints, and } \\
\text { to support the point } \\
\text { of view defended by T. } \\
\text { Ss acted in an explicit } \\
\text { manner, as protagonists } \\
\text { and antagonists. }\end{array}$ & $\begin{array}{l}\text { S were responsive } \\
\text { to the questions } \\
\text { raised by T. They } \\
\text { acted with other Ss } \\
\text { and with T. Explicit } \\
\text { arguments and } \\
\text { points of view. They } \\
\text { acted as protagonists } \\
\text { and antagonists. } \\
\text { They used } \\
\text { information from } \\
\text { the book and from } \\
\text { experiences of daily } \\
\text { life, to structure } \\
\text { their arguments. }\end{array}$ & $\begin{array}{l}\text { S are responsive } \\
\text { to the questions } \\
\text { asked by T. They } \\
\text { are explicitly } \\
\text { protagonists, } \\
\text { restructuring } \\
\text { points of view and } \\
\text { arguments. They } \\
\text { have interacted } \\
\text { mainly with the } \\
\text { teacher and have } \\
\text { used experiences } \\
\text { of daily life to } \\
\text { structure the } \\
\text { arguments. }\end{array}$ & $\begin{array}{l}\text { S were responsive to } \\
\text { the questions asked } \\
\text { by T. They interacted } \\
\text { with other Ss and } \\
\text { with T. They acted in } \\
\text { an explicit manner, } \\
\text { as protagonists and } \\
\text { antagonists. Some S } \\
\text { defended the same } \\
\text { point of view as T } \\
\text { and used information } \\
\text { from the text read } \\
\text { by the class group } \\
\text { to structure the } \\
\text { arguments. }\end{array}$ \\
\hline
\end{tabular}

$\mathbf{T}=$ teacher; $\mathrm{S}=$ students.

In both groups considered, more interaction between peers and more use of resources such as books/textbooks occurred in the lessons on Mutualism (EJA) and the Nervous System (Year 8). Considering the moment when the class groups were formed and when they started to work with the teacher, these lessons occurred: i) in the EJA group, after about 18 months; ii) in the Year 8 group, after some 21 months. This meant that, in these class groups, the discursive interactions between the members, over time and during the events, favoured greater interaction between the students.

On analysing these discursive actions of lessons on Mutualism and Nervous 
System in greater detail, we can see that the students have also been influenced and have guided their discourse accordingly. In the lesson on Mutualism (Figure 10), for example, the information from the book, as Marcellus mentioned (L257), gave direction to the discussion and was also used as a starting point for the colleagues Erika (L265) and Gabriella (L270) construct arguments, who started to raise hypotheses about the relationship between the crocodile, the crocodile bird (Pluvianus aegyptius, also known as the Egyptian plover) and the leech. This action taken by student Marcellus has also stimulated the participation of Alessandra (L273), who brought an example in which an excessive number of leeches was harmful to another animal, and could be harmful to the crocodile.

Figure 10. An excerpt of the transcription of the lesson about Mutualism - EJA group

\begin{tabular}{|c|c|}
\hline 256 & $\begin{array}{l}\text { Teacher: This looks more like this one over here / as they are together/ because there is no } \\
\text { requirement / the crocodile manages to live there / if the bird does not exist / }\end{array}$ \\
\hline 257 & $\begin{array}{l}\text { Marcellus: But here / it is the following / Inside the crocodile's throat leeches are also sheltered } \\
\text { / isn't it? / }\end{array}$ \\
\hline 258 & Teacher: Yeah? / Does it catch leeches too? \\
\hline 259 & $\begin{array}{l}\text { Marcellus: He takes them out of the crocodile's throat / one helps the other as well / isn't it? / The } \\
\text { Bird gets food and also helps the crocodile by removing the leeches there / }\end{array}$ \\
\hline 260 & Teacher: Yes, indeed / \\
\hline 261 & Marcellus: [Inaudible] it won't be because of the fish's flesh / it is a matter of the leeches \\
\hline 262 & Teacher: I didn’t know this, about the leeches / I knew it would pick meat / \\
\hline 263 & Marcellus: Not the meat / The meat is from leeches, as I said / \\
\hline 264 & Teacher: Then / \\
\hline 265 & Erika: But isn't there a way for the crocodile to swallow the leech? / \\
\hline 266 & $\begin{array}{l}\text { Marcellus: From what I read in the book / I don't know if the book was lying or not / but from } \\
\text { what I read there / the leeches stay in the crocodile's throat [he speaks looking at the teacher] }\end{array}$ \\
\hline 267 & $\begin{array}{l}\text { Teacher: But if / for example / you have the crocodile bird / and there is no crocodiles where it } \\
\text { lives / does the bird die / or does the bird get its food in a different way? / I also think it gets food } \\
\text { another way / So / Mutualism is when it is compulsory / An example of mutualism / }\end{array}$ \\
\hline 268 & Gabriella: The crocodile bird finds other types of food / \\
\hline 269 & Teacher: Yes, it manages it / I think so / \\
\hline 270 & $\begin{array}{l}\text { Gabriella: It could be a relief for the crocodile / when this bird cleanses out the crocodile's } \\
\text { throat / }\end{array}$ \\
\hline 271 & $\begin{array}{l}\text { Teacher: It is a relief / but in this way / it is not something mandatory / And if there is no } \\
\text { crocodile bird will the leech kill it? }\end{array}$ \\
\hline 272 & Students: [Inaudible] (many speaking at the same time) \\
\hline 273 & $\begin{array}{l}\text { Teacher: No / but the leech / the crocodile also has its own defences to expel the leeches / it } \\
\text { produces an acid / something there / I don't know / I am thinking here / Sometimes / it shall } \\
\text { bring it harm / but it will not arrive / only if it is very near, to kill the leech / }\end{array}$ \\
\hline 274 & $\begin{array}{l}\text { Student: (difficult to identify and to understand, but it seems that she is talking about a case of } \\
\text { cattle dying because of the leeches in the stream) }\end{array}$ \\
\hline 275 & Teacher: If there are many / then it gets dangerous / \\
\hline
\end{tabular}


Apart from using a resource for the discourse of colleagues, we can also observe that the information about the leech, as Marcellus brought, has also helped the discourse of the teacher, acting as an antagonist through questions. First. Domingos queried Marcellus, seeking additional clarification of the information (L258). Then, he challenged the validity of this information, at two different moments. First, in the sense that, to be a case of Mutualism, it would be necessary for the relationship to be mandatory, both for the crocodile and for the crocodile bird (L267). Second, in the senses of checking if this information is really mandatory, to the point of causing the death of the crocodile in the absence of the crocodile bird (L271 and L273).

In the class interactions about the Nervous System (Figure 11), we can also see how the students made use of information from the text as a resource, and had an influence on each other and on the teacher. Iago consulted the text that the class group read prior to the disagreement (L167). The teacher added value to the fact that the student used this resource, and asked the students to show more elements to structure their argument (L168 and L170). Peter showed a counterargument to the position that the format with sharp corners is safer (L173). However, the teacher asked if the colleagues heard the student (L176), stressing the importance of listening to the colleague in order to participate in the discussion. The teacher then asked him to repeat (L178), adding value to the student's opinion. Peter's counterargument (L179) was used as a base for the reasoning made by Joanna (L185), who had been invited by the teacher to make a statement (L180). This reasoning made by Joanna was counterargued by Iago (L186), who supported Peter. However, before Joanna presented her reasoning, the teacher formulated the student's position for the class group, acting as an antagonist, challenging the validity of this position on referring to 'the luck of falling straight'. Moreover, she invited the other students to participate in the discussion (L183).

Figure 11. An excerpt of the lesson on the Nervous System - Year 8 group

\begin{tabular}{|l|l|}
\hline 167 & $\begin{array}{l}\text { Iago: I think the round shape would be better / I think that in this regard / (speaks checking the } \\
\text { information in the book) / the meninges / they leave the skull [inaudible] / }\end{array}$ \\
\hline 168 & $\begin{array}{l}\text { Teacher: Iago was very smart / He went to seek elements on the sheet itself / to say that even if } \\
\text { / there was this difference in format / the brain has what? / What did you find there? / }\end{array}$ \\
\hline 169 & Iago: the meninges / \\
\hline 170 & Teacher: The meninges that were going to do what? / \\
\hline 171 & Iago: they were going to keep it stopped / \\
\hline 172 & $\begin{array}{l}\text { Teacher: Stopped / stabilised / So / that's a point / because they are also for protection / Pedro } \\
\text { / you can speak now }\end{array}$ \\
\hline 173 & $\begin{array}{l}\text { Peter: I think that if it were square / even in the right format [the skull] / when it fell / if the } \\
\text { corners took a blow / this could hurt someone / }\end{array}$ \\
\hline 174 & Teacher: What did you say? (asks, looking at Fabrice) \\
\hline 175 & Fabrice: I agree with him / \\
\hline 176 & Teacher: He is agreeing / Did you all here what Peter said? / \\
\hline
\end{tabular}




\begin{tabular}{|l|l|}
\hline 177 & Marius: No / \\
\hline 178 & Teacher: Peter / repeat louder / please / \\
\hline 179 & Peter: Because if this was a perfect square / when it falls / the corners could hurt someone / \\
\hline 180 & Teacher: Well, indeed / Joanna / and then what? / \\
\hline 181 & Joanna: Could it or not? / \\
\hline 182 & The students answered in unison: It could / \\
\hline 183 & $\begin{array}{l}\text { Teacher: It could / it may / Because Joanna always said something / that if we fell we would be } \\
\text { straight / Always with one side to the ground / But what would happen is we fell or bumped at } \\
\text { the tip / What do you think? / }\end{array}$ \\
\hline 184 & $\begin{array}{l}\text { Many students speak at the same time. It is possible to hear: 'it would get crushed' 'it would } \\
\text { break' }\end{array}$ \\
\hline 185 & $\begin{array}{l}\text { Joanna: I have changed my opinion a bit / It would not make any difference whether it was } \\
\text { round or square / because, if we are going to have this square part or the corner, it would only } \\
\text { (inaudible) / and if we hit the round part here / we also die / So / there is no difference / You are } \\
\text { going to die anyway / }\end{array}$ \\
\hline 186 & Iago: But the square is weaker / It has more points (inaudible) / \\
\hline
\end{tabular}

In a nutshell, we can say that there has been no significant variations over time, with regard to actions and positions taken up by the teachers. On the other hand, with regard to students, this variation was significant. In the two class groups, even though the students have always responded to the questioning of the teachers, after more coexistence time, they also showed more interaction with their peers, guiding discourse, having mutual influence upon each other and on the teachers. In addition, they have used a book/text as a resource for the construction of arguments, and taken up a stand as antagonists, explicitly presenting counterpositions.

Even though it has not been possible to show here examples of all actions and forms of positioning of each teacher, we have seen some similarities and differences between the two class groups. Both have taken up positions in depth, through questions, which allowed them to maintain their position as an implicit protagonist for a long time, during the interaction. At the same time, these issues represent the position of antagonist and had different functions. This means that both questioned the students to request more elements, provide clarifications, and challenge the validity of the information that the student has brought.

With regard to the differences, we observe that, in addition to these actions, teacher Beatrice always explicitly mentioned the importance of listening to colleagues to take part in the discussion, then prepared the views and arguments of the students, for the class group, and then invited them to state their views. In addition, then the teacher took up an explicit position, then the disagreement was finalised. A similar situation also happened to teacher Domingos, but only in the lesson on the $\mathrm{ABO}$ blood grouping system. In the lessons on Solid Residue and Mutualism, on the other hand, when the teacher took up an explicit position the disagreements continued.

Apart from these differences between the class groups, we also noticed, on analysing 
and contrasting the whole data set, variations in argumentative processes, considering the same group. In the EJA group, the process in each lesson had particularities. In the lesson on the ABO System, as teacher and students interacted through discourse, they generated new and more specific disagreements to solve the main disagreement. In the lesson on Solid Residue, the resolution process involved the disagreement based on two propositions: measurement of material or objects; and use of a conventional standard for measurement or creation of a specific measurement standard for the group. In the lesson on Mutualism, on the other hand, the greater participation of the students meant that, during the process of resolution of disagreements, there were more counterpositions, and the positions were backed up by more arguments.

In the Year 8 group, the argumentative processes also had their specificities. In the lesson on the Excretory System, the teacher's questioning helped to show and to restructure the position and the argument the students defended. These questionings also implicitly set some rules for argumentation, which the teacher used as a reference to counterargue in opposition to the students. In the lesson on the Nervous System, on the other hand, the greater interaction between the students and their peers contributed so that, in the process for resolution of disagreements, there would be counterpositions, and these positions would be sustained by more arguments. In this process, the teacher explicitly presented the rules for argumentation and, on showing the teacher's position and arguments, the teacher synthesised the contributions made by the students.

\section{Discussion}

In this section, we try to answer the question: How are the argumentative processes of the two class groups related to the construction of a classroom culture of argumentation? For the construction of the answers to this question, we consider the many different aspects related to the construction of a classroom culture of argumentation, as previously discussed in this article.

With regard to the first aspect, we notice that scientific knowledge was subject to doubts and uncertainties (Henderson et al., 2018), even though the situations when there is argumentation have predominantly been those when there has been discussion of highly conceptual objects, without much scope for changes of position, under the perspective of Science Education. This has occurred mainly due to the actions of questioning on the part of the teachers, which have resulted in the appearance of disagreements, and processes for solution thereof.

Thus, different from the study of Sandoval and collaborators (2019), the disagreements did not arise from natural disagreements between the students, but based on interventions of Domingos and Beatrice, who gave value to dialogue and the knowledge of the students as being essential in the process for construction of scientific knowledge in the classroom. These questionings also contributed to highlight the tension between scientific knowledge and that students' knowledge (El-Hani and Mortimer (2007), thereby establishing a safe environment so that the students could express their 
own positions and arguments (Henderson et al., 2018).

The second aspect of a culture of argumentation corresponds to criticism and evaluation. This occurred through interactions in which someone took on the role of antagonist, meaning non-alignment with the positions presented, whether of the text, of a student, or of the teacher himself or herself, in the case of the student. This antagonism was constructed either implicitly or explicitly; when the teacher took on the role of antagonist this was done mainly through questions. These questions normally referred to thinking in other situations, bringing new information or data on the situation as analysed, requesting that students present additional information about their statements.

The students, on the other hand, explicitly positioned themselves as antagonists, raising objections to positions and arguments (Leitão, 2000), especially when they interacted more with their peers. These interactions involved evaluation of evidence and reasoning that the colleagues presented and which, according to González-Howard and McNeill (2020) are dialogue interactions that favour criticism and evaluation. In addition, the criticism has been aimed at ideas and not at people (Henderson et al., 2018). For example, we observe that, when one student makes a counterargument regarding what a colleague has said, then the content of this talk has been considered, without any significant influence from personal relations they had between themselves; in other words, it did not matter whether they had some affinity or not with who was speaking, but if they agreed with the idea as presented.

With regard to the third aspect of a culture of argumentation, the temporal and procedural dimension, we see, for example, that the forms students interacted between themselves, developed more significantly after months of coexistence between members of the group. These results confirmed the notion that standards and expectations are constructed through discourse, over time and during events (see, for example: Dixon \& Green, 2005; Green et al., 2005; McDonald \& Kelly, 2012).

Thus, these results also help to explain why changes in practices of communities in the classroom are not trivial (Berland \& Reiser, 2011), as they demand continuous action, especially on the part of teachers. In addition, these results are coherent with the procedural dimension (Larraín \& Freire, 2011). As in the study these authors conducted, in both class groups the main focus was not that of understanding the structure of arguments, but that of establishing conditions so that students were encouraged to defend their points of view and to present criticism of the opposite ideas.

The fourth aspect of a culture of argumentation is that of diversity. The contrast between the events of the lessons in the two groups brought a lot of evidence that argumentative processes vary in the same class over time and during events, and in different groups. These results support Berland and Reiser's (2011) findings, not in relation to the objectives of persuasion and sense-making as analysed by these authors, but in the sense that there is variation in the ways in which students get involved, in different class groups, resulting in different styles of argumentation.

As in the study carried out by Baker (2015), we observed that the consideration 
of undeclared conflicts, as also doubts and questions, increases the possibilities of argumentation, and its variation. In the contexts we have studied, for example, disagreements have arisen and have been solved, mainly through questions, and have been extremely diverse. We can therefore say that other ways to argue and criticise were accepted in the class group community, as well as the dominant ways of knowing and explaining the world, as suggested by González-Howard and McNeill (2020). This acknowledgement may help the inclusion of minority groups, such as young students and adults.

With regard to the fifth and last aspect of a culture of argumentation, the social and collective dimension, we observe that the actions and communication between teachers and students are shaped by the answers (verbal or non-verbal) of other members of the class group (Dixon \& Green, 2005). For example, it becomes evident just how the information of a book, brought by a colleague, can direct the discourse of the class group, meaning that other students can get involved in the discussion of an example, thereby contributing to solve the disagreement and also leading colleagues to change their minds as they interact with their peers. In addition, this information has also moulded the actions of the teacher, who requested clarification and challenged the validity of this information. These results match those found by Rudsberg et al.(2017), which showed evidence that the students have had an influence on the reasoning of the other students.

Another aspect that we have observed is the fact that some of the teachers' actions seem to be similar to the actions that favour argumentation as described/identified in instruments of analysis from other studies, such as those Ferraz and Sasseron (2017), Ibraim and Justi (2018), and Larraín and Freire (2011) proposed. For example, there were situations in which the teachers questioned the answers of the students, in a way similar to what Ferraz and Sasseron (2017) considered Exploration; and to what Larraín and Freire (2011) classified as 'Focus on what is said by the student, in order to deepen and understand the student's point of view', and to what Ibraim and Justi (2018) considered 'Encourage the student(s) to present justifications for their statements'.

Even though they have relationships with different analytical instruments, these classifications have an element in common, which is the fact that the main goal of the teacher is to get the students to clarify, or to bring additional elements to, their points of view or arguments. However, the actions of the teachers have not always been the same, when we contrast both contexts, not even when we consider the same class group.

We therefore note that the actions of the teachers would not have favoured argumentation had the students not been positively responsive to them. This result supports the understanding that the teachers' and students' actions are directly linked related to the contexts that permeate each classroom (Ferraz \& Sasseron, 2017).

\section{Final comments}

The analyses of contrasts of argumentative processes in the EJA group and the Year 8 group of regular education, based on the characteristics of a classroom culture of argumentation, allows us to say that both class groups have characteristics of this 
kind of culture, even in instructional contexts with characteristics that apparently do not favour argumentation. Our results show that the forms teachers interact and respond to characteristics of the group can be fundamental elements in the construction of this type of classroom culture.

We do not wish to minimise the role that contexts, such as those of investigation and those involving social and scientific issues, have for the construction of this culture. Our analyses suggest, however, that the construction of such a culture is not limited to contexts like these and can occur in different ways, as long as value is attached to dialogue and knowledge of the students as essential factors for the process of construction of scientific knowledge in the classroom. This means that it is essential to challenge prospects of deficit with regard to teaching practice and classrooms in Primary Education, as if argumentation was something totally 'foreign' to aspects of classroom culture as already introduced.

Our results also show the potential of more descriptive studies, to characterise argumentation in the Science classroom. Based on in-depth descriptions and analyses of discourse interaction in the classroom, based on the theoretical and methodological grounds of Ethnography in Education and Pragma-dialectics, it has been possible to give visibility to the diversity of argumentative processes that contributes to the construction of a culture of argumentation. To expand our knowledge about this diversity, we recommend more descriptive studies, that analyse the actions of the teacher(s) in a form that is articulated with the actions and reactions of the students, that involve a longer period of time in the field for data collection, and that investigate a range of institutional and instructional contexts.

Apart from contributions to the field of research, this study also brings consequences for teachers' pedagogical practices, as the study brings elements that show how the interaction between teachers and students create possibilities for argumentation, even in more traditional instructional contexts such as lecture-dialogue lessons and correction of exercises. This knowledge may provide guidance for courses and disciplines in Teacher Education.

\section{Acknowledgments}

We would like to thank CAPES for their financing through a PNPD grant which gave us the possibility to enhance the alternative theoretical and methodological approach for the study of argumentation, proposing relationships between Ethnography in Education and Pragma-dialectics, and a greater understanding of the characteristics of a classroom of argumentation - and for the doctoral grant that enabled the collection and analysis of data in the Year 8 class of regular Primary Education, and the proposal of an alternative theoretical and methodological approach for the study of argumentation in Science lessons. We would also like to thank CNPq for the financial resources of the Ciência na Escola Project, bolsa pesquisador e and master's studies grant, which have enabled the collection and analysis of data in the EJA group, and the first approximation between Ethnography in Education and the Pragma-Dialectics theory of argumentation. 


\section{References}

Baker, M. J. (2015). The integration of pragma-dialectics and collaborative learning research: dialogue, externalisation and collective thinking. In F. A. van Eemeren, \& B. Garssen (Eds.) Argumentation in Context, 175-199. Amsterdam: John Benjamins Publishers.

Berland, L. K., \& Hammer, D. (2012). Framing for Scientific Argumentation. Journal of Research In Science Teaching. 49(1), 68-94.

Berland, L. K., \& Reiser, B. J. (2011). Classroom communities' adaptations of the practice of scientific argumentation. Science Education, 95(2), 191-216.

Billig, M. (1987) The art of witcraft. In M. Billig. Arguing and thinking: A rhetorical approach to social psychology (82-117). Cambridge University Press.

Bloome, D., Carter, S. P., Christian, B. M., Otto, S., \& Shuart-Faris, N. (2005) Discourse Analysis and the study of classroom language and Literacy Events: a Microethnografic perspetive. Lawrence Erlbaum Associates.

Castanheira, M. L., Green, J. L., \& Dixon, C. N. (2007) Práticas de letramento em sala de aula: uma análise de ações letradas como construção social. [Literacy practices in classrooms: Examining literate actions as socially constructed] Revista Portuguesa de Educação, 20(2), 7-38.

Dixon, C., \& Green, J. (2005). Studying the Discursive Constructions of Texts in Classrooms Through Interactional Ethnography. In R. Beach, J. Green, M. Kamil, \& T. Shanahan (Eds.), Multidisciplinary Perspectives on Literacy Research (2 ed.). Santa Barbara: Hampton Press Cresskill.

Duschl, R. (2008). Science Education in Three-Part Harmony: Balancing Conceptual, Epistemic, and Social Learning Goals. Review of research in Education, 32(1), 268-291.

EL-Hani, C. N. \& Mortimer, E. F. (2007). Multicultural Education, Pragmatism, and the Goals of Science Teaching. Cultural Studies of Science Education, 2(3), 657-687.

Ferraz, A. T., \& Sasseron, L. H. (2017). Propósitos epistêmicos para a promoção da argumentação em aulas investigativas. [Science Teaching and epistemic practices: teachers' role and students' engagement] Investigações em Ensino de Ciências, 22(1), $42-60$.

González-Howard M, McNeill KL. (2020). Acting with epistemic agency: Characterizing student critique during argumentation discussions. Science Education. 1-30. https://doi. org/10.1002/sce.21592

Green, J., Dixon, C., \& Zaharlick, A. (2005) A etnografia como uma lógica de investigação. [Ethnography as a logic of inquiry]. Educação em Revista, 42, 13-79.

Henderson, J. B., McNeill, K. L., González-Howard, M., Close, K., \& Evans, M. (2018). Key Challenges and Future Directions for Educational Research on Scientific Argumentation. Journal of Research in Science Teaching, 55(1), 5-18. 
Ibraim, S. de S., \& Justi, R. (2018). Ações docentes favoráveis ao ensino envolvendo argumentação: estuda da prática de uma professora de química. [Teachers' Actions that Support Argumentation-based Teaching: Analysis of a chemistry teacher's practice.] Investigações em Ensino de Ciências, 23(2), 311-330.

Jiménez-Aleixandre, M. P. \& Erduran, S. (2007). Argumentation in Science Education: An Overview. In M. P. Jiménez-Aleixandre, \& S. Erduran. Argumentation in Science Education: perspectives from classroom-based research (03-25). Springer.

Kelly, G. J. (2005) Discourse, description, and science education. In R. Yerrick, W. M. Roth (eds), Establishing Scientific Classroom Discourse Communities: Multiple Voices of Research on Teaching and Learning (79-108). Mahwah, NJ: Lawrence Erlbaum.

Larrín, A. \& Freire, P. (2011). Capitalizando a controvérsia: algumas reflexões para tornar visível e aproveitar a contra-argumentação dos alunos no Ensino de Ciências. [Capitalizing controversy: some reflections to make visible and to use students counter argumentation in Science teaching] In S. Leitão, \& M. C. Damianovic (Orgs.), Argumentação na escola: o conhecimento em construção [Argumentation at school: Knowledge in construction] (47-80). Campinas, SP: Pontes Editores.

Leitão, S. (2000). The potential of argument in knowledge building. Human development. $43(6), 332-360$.

Lincoln, Y. S., \& Guba, E. G. (1985) Naturalistic inquiry. Sage Publications, Inc.

McDonald, S. P., \& Kelly, G. J. (2012) Beyond Argumentation: Sense-Making Discourse in the Science Classroom. In M. S. Khine (ed) Perspectives on Scientific Argumentation: Theory, Practice and Research (265-281). Springer.

McNeill, K. L., \& Pimentel, D. S. (2010) Scientific discourse in three urban classrooms: The role of the teacher in engaging high school students in argumentation. Science Education, 94(2), 203-229.

Munford, D., \& Teles, A. P. S. S. (2013). Argumentação e construção de oportunidades de aprendizagem em aulas de Ciências sobre Corpo Humano em uma turma do $8^{\circ}$ ano do ensino fundamental. [Arguing and constructing learning in science lessons about human body in a 8th grade class] In IX ENPEC - Encontro Nacional em Pesquisa em Educação em Ciências, Águas de Lindóia. Atas do IX Encontro Nacional de Pesquisa em Educação em Ciências IX ENPEC, 1-8.

Munford, D., \& Teles, A. P. S. S. (2015). Argumentação e a construção de oportunidades de aprendizagem em aulas de Ciências. [Argumentation and learning opportunities construction in science classes] Ensaio: Pesquisa em Educação em Ciências, 17, 161-185.

Rex, L. A. (2006). Introduction. In L. A. Rex (ed.) Discourse of opportunity: How talk in learning situations creates and constrains (1-35). Hampton Press Inc.

Rudsberg, K., Östman, Leif. \& Östman, Elisabeth. A. (2017) Students’ meaning making in classroom discussions: the importance of peer interaction. Cultural Studies of Science Education 12, 709-738. https://doi.org/10.1007/s11422-015-9721-5 
Sandoval, W. A., Enyedy, N., Redman, E. H. \& Xiao, S. (2019): Organising a culture of argumentation in elementary science. International Journal of Science Education, 4, 1848-1869. https://doi.org/10.1080/09500693.2019.1641856

Schwarz, B. B. (2009) Argumentation and Learning. In N. M. Mirza, \& A. N. P. Clermont (eds), Argumentation and Education: Theoretical Foundations and Practices (91-126). London, Springer.

Skukauskaité, S., Liu, Y., \& Green, J. L. (2007). Editorial Introduction: Logics of Inquiry for the Analysis of Video Artefacts: Researching the Construction of Disciplinary Knowledge in Classrooms. Pedagogies: an International Journal. 2(3), 131-137.

Spradley, J. (1980) Participant observation. Holt, Rinehart; Winston.

Stake, R. E. (1998). Case Studies. In N. K. Denzin, \& Y. S. Lincoln. Strategies of Qualitative Inquiry (86-109). Thousand Oaks, SAGE Publications.

van Eemeren F. H., Grootendorst, R. (2004) A Systematic Theory of Argumentation: The pragma-dialectical approach. Cambridge University Press.

van Eemeren, F. H., Grootendorst., R., \& Henkemans, A. F. S. (2002). Argumentation: Analysis, Evaluation, Presentation. New Jersey, Lawrence Erlbaum Associates.

\author{
${ }^{10}$ Ana Paula Souto Silva Teles \\ Federal University of Minas Gerais \\ School of Education, Belo Horizonte \\ Minas Gerais, Brazil \\ anapaulasoutos@gmail.com
}

${ }^{-}$Danusa Munford

ABC Federal University

Centre for Nature Science and Humanities Santo André, São Paulo, Brazil danusa.munford@ufabc.edu.br

Editor in charge

Marta Maximo

Disclosure statement

No potential conflict of interest was reported by the authors.

Compliance with Ethical Standards

The authors declare this study was conducted following ethical principles. 